\title{
Solar PV Electrification in Nigeria: Current Status and Affordability Analysis
}

\author{
Ogheneruona Endurance Diemuodeke ${ }^{1 *}$, Yacob Mulugetta ${ }^{2}$, Henry Ifeanyi Njoku ${ }^{3}$, \\ Tobinson Alasin Briggs' ${ }^{1}$ Mohammed Moore Ojapah1
}

${ }^{1}$ Department of Mechanical Engineering, Faculty of Engineering, University of Port Harcourt, Port Harcourt, Nigeria ${ }^{2}$ Department of Science, Technology, Engineering \& Public Policy (STEaPP), University College London, London, UK ${ }^{3}$ Department of Mechanical Engineering, School of Engineering and Technology, Federal University of Technology, Owerri, Imo State, Nigeria

Email: *ogheneruona.diemuodeke@uniport.edu.ng

How to cite this paper: Diemuodeke, O.E., Mulugetta, Y., Njoku, H.I., Briggs, T.A. and Ojapah, M.M. (2021) Solar PV Electrification in Nigeria: Current Status and Affordability Analysis. Journal of Power and Energy Engineering, 9, 1-25.

https://doi.org/10.4236/jpee.2021.95001

Received: February 8, 2021

Accepted: April 27, 2021

Published: April 30, 2021

Copyright $\odot 2021$ by author(s) and Scientific Research Publishing Inc. This work is licensed under the Creative Commons Attribution International License (CC BY 4.0).

http://creativecommons.org/licenses/by/4.0/

\begin{abstract}
Rural households represent, by far, the greater percentage of dwellings globally without access to the electricity supply. For reasons of low loads, distance from the grid and speed of deployment, distributed energy systems are now considered viable options for rural electrification. This paper presents the status of solar Photovoltaic (PV) in Nigeria and discusses the way forward for aggressive PV penetration in Nigeria's energy mix, especially in rural communities. At present, distributed PV penetration in Nigeria is comparatively low based on the International Energy Association's recommended PV market potential. This shows that there is a gap between the government's policy targets and reality. The solar resource potential across the six geo-political zones in Nigeria is also presented, which ranges from $3.393-6.669 \mathrm{kWh} /$ $\mathrm{m}^{2} /$ day, with the Northern zones exhibiting better potentials over the Southern zones. It is shown that the levelised cost of electricity from PV system ranges from $0.387-0.475 \$ / \mathrm{kWh}$, whereas it is $0.947 \mathrm{US} \$ / \mathrm{kWh}$ and 0.559 US $\$ / \mathrm{kWh}$ for the diesel generator and glass-covered kerosene lamp, respectively. While this study shows that PV for rural household lighting is more affordable as compared to glass-covered kerosene lamps and fossil-fuelled generators for lighting, fiscal and energy policies for market creation are critical if PV systems are to deliver on their promise for rural electrification and climate change mitigation.
\end{abstract}

\section{Keywords}

PV Electrification, Levelized Cost of Energy, PV Penetration, Solar Resource Potential, Affordability Index 


\section{Introduction}

There is a growing interest in the development and deployment of renewable energy technologies (RETs) as a result of the rapidly declining cost of solar photovoltaic (PV), climate action and energy security. These qualities form the bases for the search for clean, adequate and affordable energy solutions, as stipulated in the No. 7 of the 17 Sustainable Development Goals (SDGs) [1]. Clean, adequate and affordable energy supply in a nation state means the provision of technologies (skills and infrastructures) capable of producing and supplying adequate and uninterrupted energy to meet household, corporate and national energy demands [2]. However, there is a significant access gap in electrical energy globally where about 1.3 billion people live without electrical energy [3]. Sub-Saharan Africa accounts for over 600 million people of the population of people living without electricity, which can be attributed to the poor development progress, both in technological development and human development, of the sub-Saharan Africa nations [4].

There is sufficient evidence from the literature that suggests a correlation between the application of renewable energy technologies (RETs) and sustainable development [5]-[14]. As a result, the use of PV systems for the generation of electrical energy has been rapidly increasing globally. PV systems are now seen as important options for bridging the gap between the current electrical energy supply and demand through a wide range of applications [3] [9] [15] [16] [17]. PV systems have gained significant acceptance and application in the developed nations with Germany leading the pace, after China, having installed capacity of about $40 \mathrm{GW}$ [18]. However, Africa's total cumulative installed capacity of PV at the end of 2015 remains very low at $2.1 \mathrm{GW}$, which amounts to just above $5 \%$ of Germany's installed capacity. This comparatively low penetration level is paradoxical given that countries across Africa are endowed with abundant solar insolation levels.

Nigeria lies between $4-14^{\circ} \mathrm{N}$ and $3-15^{\circ} \mathrm{E}$ with a land area of about 923,800 $\mathrm{km}^{2}$. Nigeria is the most populous country in Africa with about 170 million people and comparatively very large primary energy potentials. However, Nigeria is useful-energy starved as only about $10 \%$ of the rural dwellers and $40 \%$ of the urban dwellers have access to the national electricity grid supply [19]. Nigeria has the highest duration of a power outage in Africa [20]. Out of the projected daily peak electricity demand of 25,800 MW in Nigeria, the average daily peak supply is $3140 \mathrm{MW}-87.8 \%$ unsatisfied projected demand-with about $20 \%$ distribution/transmission loss. Specifically, the total installed capacity of the power plant is currently at $12,522 \mathrm{MW}$; whereas, non-available capacity is about $5500 \mathrm{MW}$ and non-operational capacity is about $3200 \mathrm{MW}$ [19] [21]. Nigeria's electrification rate is estimated to be $45 \%$, whereas Ghana and Morocco parade superior electrification rates of $72 \%$ and $98 \%$, respectively, over Nigeria [22] [23] [24]. Although Nigeria's electrification rate is on a steady increase, but the rate of growth falls short of meeting electricity demand as the country's electrical 
energy generation growth rate is put at $93 \%$ over 20 years horizon, whereas Indonesia and Bangladesh growth rates are, respectively, put at $372 \%$ and $451 \%$ in the same time horizon [24]. The current underperformance of the Nigerian electricity system can be attributed to a number of reasons: weak political will to invest in the energy sector, limited transmission and distribution network, the poor maintenance culture, grossly inadequate production capacity, the disruption of the system by conflict, vandalism, lack of continuity in government's energy plans/projects, and the economic sabotage [2].

The Federal Government of Nigeria (FGN) has made some efforts to expand the energy mix to include conventional energy generation (fossil-driven), RETs and nuclear energy technology. However, the energy mix is currently tilted to the conventional energy generation, and the available energy policies suggest that the conventional energy generation will continue to take up a large share of the energy mix, implying increased contribution to negative environmental impact and energy insecurity [25]. Whilst conventional systems will remain important for Nigeria's energy mix, RETs also offer new possibilities for areas where access is low and supply is unreliable. Nigeria has the potentials for cleaner energy development-namely wind, solar, hydro etc. It is estimated that Nigeria receives $3.5-7.0 \mathrm{kWh} / \mathrm{m}^{2} /$ day of solar insolation [26]. The solar insolation across Nigeria is greater than that across Germany by about $60 \%-83 \%$, yet the installed solar capacity in Germany is about 12 times greater than the total peak electricity generation in Nigeria. In addition to the favourable renewable resource base for energy applications, PV electrification has an added advantage of being among the shortest project lead times in power generation projects. This is very crucial in Nigerian political landscape where the lack of continuity in government's plans/projects after a preceding government often leads to abandonment of projects [27].

Shaaban and Pentinrin [28] articulated the existing FGN's energy policies and proposed energy policy pathways that would induce RET utilisation in the country. However, energy policy pathways without adequate consideration of the economic affordability of the rural dwellers or the energy entrepreneur may be an effort in futility [29] [30]. Akuru et al. [31] positioned that the current effort of the Nigerian government to provide adequate, available and stable electrical energy can only be achieved by rapid diversification of sources of electrical power in the country. They stressed a model scenario and field experience that it is much easier to achieve $100 \%$ renewable energy through the individual installation of renewable energy technologies, with solar PV playing a major role. However, economic index (especially from the rural dwellers perspective) that surrounds solar PV utilisation for individual installation was not addressed.

Nwokocha et al. [32] showed that PV is a more viable RET option for providing sustainable energy needs in Nigeria, especially for the rural dwellers. The authors also suggested pointers to solve PV utilisation in Nigeria. However, affordability of PV energy utilisation was not addressed, even though many authors have suggested that economic challenges should be given utmost priority 
for the general acceptance of PV in sub-Saharan Africa, and to simultaneously achieve the objectives formulated in the SDGs [33] [34].

The SDGs' objectives support universal access to electric lighting. The lack of electricity in the majority of the rural communities and the erratic electricity supply in the urban communities of sub-Saharan Africa favour the lighting options driven by kerosene lamps, candle, wood and other fossil powered conventional lighting devices [35]. Replacing fossil powered lighting devices with modern lighting appliances is an important aspect of meeting the SDGs' objectives [36]. The fossil-based lighting devices are attributed to public health and safety risks [37]. PV driven lighting appliances enhance community life through socialising, longer hours of studying and reading, cooking, commerce, night-time security, health care and many others [38].

The poor PV penetration in Nigeria could be attributed to some identified barriers; namely lack of awareness and information about PV technologies, high initial investment cost, perceived high cost of unit energy consumed, lack of technically skilled personnel, government policy and incentives, ineffective quality control of products, government weak political wills towards PV utilisation and vandalism of PV infrastructure [3] [8]. All these barriers could be grouped into cost-effectiveness/affordability issues, issues with financing, techno-management related issues and policy issues. The affordability and policy issues have been identified as the epicentre of the obstacles to PV penetration in Nigeria [39]. However, evidence from available literature indicates that decentralized sustainable solar electrification systems offer keyways to unlocking the electricity access problem in Nigeria [40].

PV rural electrification is gaining significant research attention in recent decades, most especially in the developing nations. The affordability and appropriateness of PV rural electrification in sub-Saharan Africa (SSA) countries were conducted by Baurzhan and Jenkins [39]. The authors showed that PV is appropriate for rural electrification in SSA. The authors, however, noted that while costs of PV electrification have come down dramatically across the globe, the costs in SSA remain much higher than the world average due to a variety of reasons including the cost of imported components. Hence, the high cost of electricity generation from PV in SSA is often offset by support from donors to make these systems affordable for rural households. The establishment of a Nigerian PV panel manufacturing plant at Karshi (Abuja) with a capacity of 7.5 MW/year in 2014, a joint venture involving the National Agency for Science and Engineering Infrastructure (NASENI) and a foreign partner, may bring down the cost of PV systems, which would make PV electrification more competitive in Nigeria. The affordability index of solar PV driven lighting appliances, from the perspective of the rural dwellers, has not been matched with the fossil driven lighting devices in the available literature in the public domain. This paper, therefore, aims to establish the current PV penetration in Nigeria's energy mix and to address the PV unit cost of energy and its affordability index against selected fossil driven lighting options across the six geo-political zones of Nigeria. 


\section{Methodology}

The methodology adopted in this paper is divided into four major components, as shown in the research methodology framework presented in Figure 1. The research framework is intended for order and ease of adaptation of the research methodology. The research framework is fashioned to promote input-output relationship as the outputs from a phase form the inputs of subsequent phases. Boundary and assessment of the current PV penetration in Nigeria are presented in Section 2.1. Section 2.2 is on the assessments of solar resource and electrical load demand, which gives input to the technical feasibility study and financial pre-feasibility studies, as shown in Section 2.3. Furthermore, Section 2.3 presents the optimal design of a standalone PV system under the prevailing techno-economic conditions. Section 3.4 is on sensitivity analysis, which focuses on the competitiveness of PV under identified technical or economic or policy parameters.

\subsection{Boundary and Assessment of Current Solar PV Penetration}

Nigeria has a population of about 170 million people and comparatively very large primary energy potentials. About 93 million Nigerians live without electricity, with the majority concentrated in the rural communities. The country is divided into six geo-political zones, namely North-Centre zone, North-East zone, North-West zone, South-East zone, South-South zone and South-West zone, which are delineated in Figure 2 [41]. Abuja serves as the Federal Capital Territory, which is the administrative centre of the country. Nigeria has 36 federating units called the states, with an average of six states per a geo-political zone.

The Federal Government of Nigeria (FGN), through the National Renewable Energy and Energy Efficiency Policy (NREEEP), plans to vigorously pursue the deployment of PV in its electricity generation [19]. The NREEEP targets 117 MW, $1343 \mathrm{MW}$ and $6830 \mathrm{MW}$ solar electricity generation capacity by the year 2015, 2020 and 2030, respectively. The NREEEP solar electricity generation projections are based on off-grid and on-grid power and a base capacity of 12,500 MW of self-generation. The 2015 estimation of PV installation in Nigeria is put

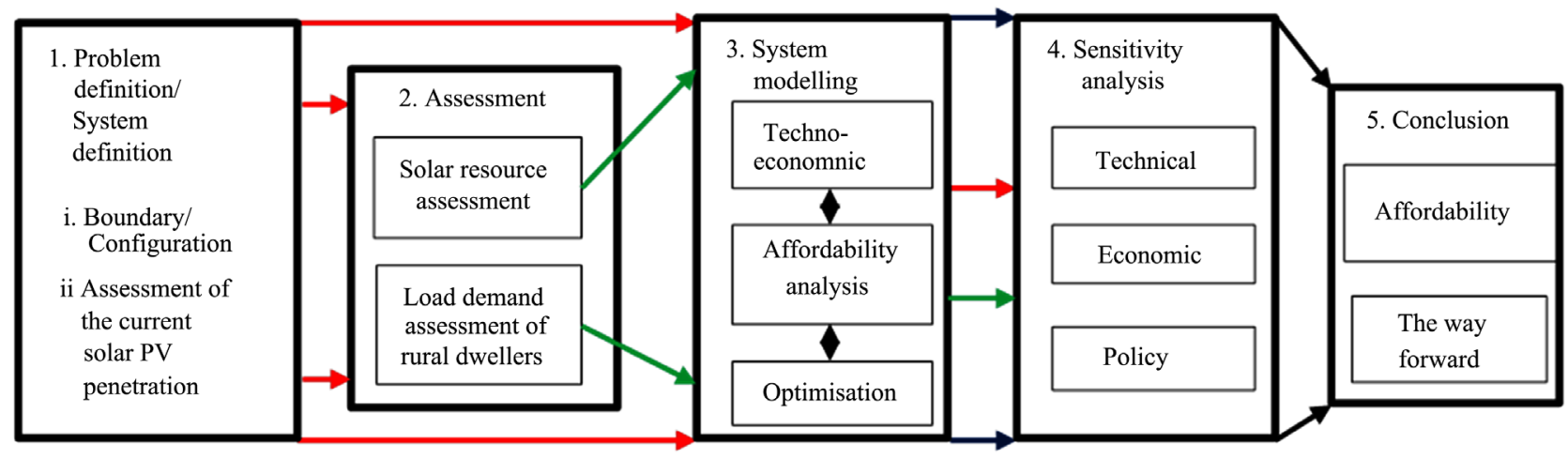

Figure 1. Research methodology framework. 


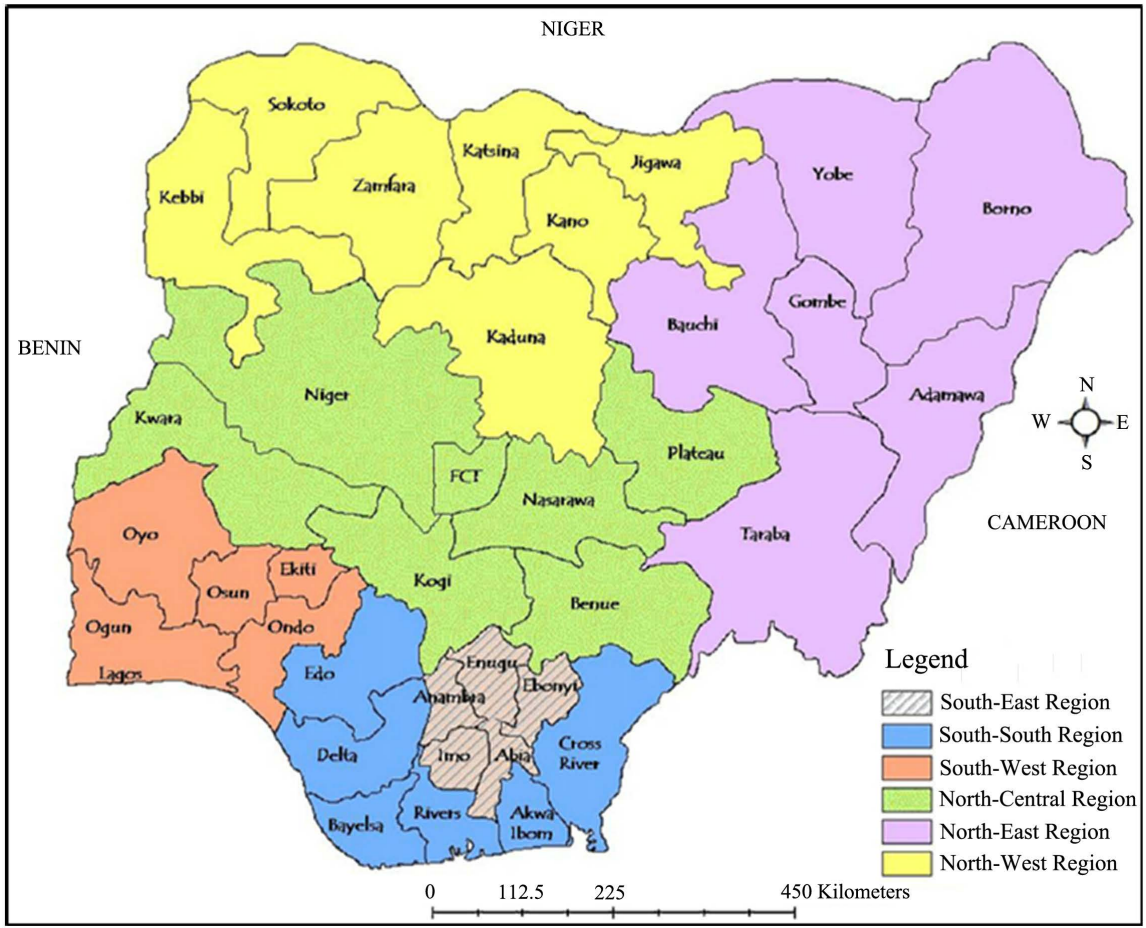

Figure 2. Nigeria map showing geo-political zones [41].

at $15 \mathrm{MW}$, without the consideration of PV (Pico) and other small power rating appliances [24]. Though the NREEEP targets are based on total solar PV (off-grid and grid-tied) and solar thermal installations, but the gap between the NREEEP target for 2015 and the real PV installation on the ground is significant since there is no evidence of grid-tied PV electrification in the year 2015, even up to the third quarter of 2019. The gap may be attributed to some of the identified challenges facing renewable energy technology utilisation in sub-Saharan Africa countries [42]. However, inadequate economic evaluation of RET systems, technology-know-how, and improper implementation, monitoring and evaluation of energy policies may be considered as the most prominent challenges militating against RE utilisation in Nigeria. Ozoegwu et al. [43] suggested that a holistic evaluation of economic affordability of RET, backed with workable government energy policy, is a priority in diffusing RETs to the rural communities. Much was made of the fact that the FGN's National Agency for Science and Engineering Infrastructure's (NASENI) PV panel manufacturing plant at Karshi (Abuja) would stimulate the rapid deployment of PV systems across Nigeria. However, this ambition is yet to be materialised as the 7.5 MW annual production capacity of NASENI PV panels, without considering the frequent below capacity production, is still too low to transform the solar energy industry [8] [26] [44].

The FGN's efforts towards solar electrification seem to be heavily tilted towards grid- and mini-grid-connected electrification. The FGN's efforts, through the Nigerian Bulk Electricity Trading (NBET), may increase the share of grid-connected PV by $1167 \mathrm{MW}$ in the year 2025 [45] [46] [47] [48]. The 
grid-connected PV projects have not progressed satisfactorily as expected since none of the projects has reached financial close in the first quarter of 2018 after the Power Purchasing Agreements (PPAs) were signed in 2016. It is often argued that large grid-connected mega-watts PV project are considered to be relatively cheap compared to the stand-alone PV applications. However, this logic excludes the majority of the rural communities that are not connected to the national grid. Connecting such remote and dispersed communities to the national grid may not be possible in the short and medium terms, for reasons of high financial investment required to achieve this goal under the existing FGN's energy plans [26]. Hence, for the about 93 million Nigerians with no access to electricity [49], smaller-scale off-grid PV systems application could be considered as a promising solution to address the immediate electricity needs at the household and institutional levels such as rural health centres, telecommunication, water pumping and schools. Often these entities either operate with no electricity or operate unreliable diesel systems, and the adoption of PV offers one way to meet the energy security challenge that is facing the rural communities. There are evidence of on-going off-grid PV projects in the country. For example, the Lagos State Government, in collaboration with the UK Department for International Development, is currently developing a $5 \mathrm{MW}$ off-grid of PV electrification to power public schools and healthcare centres within the Lagos State. The Bank of Industry is currently running a $24 \mathrm{~kW}$ off-grid PV electrification project in Kaduna State [47] [48]. Observation has also shown that a number of wealthy homes and businesses are using PV to argument the unreliable electricity supply from the national grid.

However, a need assessment conducted in 2018 suggests that there is a significant gap between energy demand and supply in Nigeria and that the country needs to connect between 500,000 to 800,000 households per year (about 2.5 to 4.0 million people per year) to achieve universal access to electricity by 2030 . Besides the household energy access, aggressive energy supply for productive end-uses is also desirable [50]. The evidence on the ground shows that there is a significant gap between the NREEEP targets for 2020 and the reality [50] [51], which may also hold for the other targets since the FGN's on-grid PV projects have not progressed beyond signing of PPAs. It is evident that the NREEEP target penetration is able to meet the International Energy Association's potential market ${ }^{1}$ potential market by the end of 2020 and beyond, but it may not be possible to meet the targets judging from the current PV penetration in the country. The implication is that a majority of the rural dwellers will continue to live without the modern energy in Nigeria since there is a gap between the current penetration and the IEA's potential market. The off-grid energy solutions, in which solar electrification plays prominent, were tipped to meet the energy demand of the rural communities in the medium term since the grid is challenged with a limited and weak network [50]. Here lies the significance of a ${ }^{1}$ According to the International Energy Association, the potential market for solar household systems is $20 \%$ of the total population without access to electricity [52]. 
proper energy policy and intensive energy research and development efforts to intensify the PV penetration in rural communities.

\subsection{Assessment of Solar Energy Resources and Load Demand}

\subsubsection{Solar Resource Assessment}

The Nigerian Meteorological Agency (NIMET) database and the Typical Meteorological Year (TMY2) data, which include solar irradiance and ambient temperature, from both the NASA Surface Meteorology database and US National Renewable Energy Laboratory (NREL) database serve as the sources of data for the assessment. The data retrieved from NREL are in good agreement with onsite solar data obtained from meteorological stations in Africa continent as presented in the literature in the public domain [53]. In what follows, the TMY solar resource assessment is adjudged adequate for long-term solar energy system performance evaluation. The solar energy assessment was done for the entire country by triangulation according to the six geo-political zones. The triangulation identified six representative sites, which cover the entire country, as shown in Table 1.

\subsubsection{Electrical Energy Demand Assessment}

There are varied daily energy demand profiles reported in the literature for $\mathrm{Ni}$ geria households [54] [55] [56]. The variation in the energy demand profile could be attributed to the location of the building, income of dwellers, access to the national grid, energy management, attitude towards energy consumption and the type of energy demand (electrical and thermal). However, the daily energy demand profile presented by Diemuodeke et al. [56], replicated in Figure 3, which may be biased towards the SS zone, is considered to be a typical electrical energy demand profile of a rural household without access to the national grid. Therefore, the daily electrical energy demand profile presented in Figure 3 is adopted as the representative household demand load. The total daily electrical energy demand of the representative household is $7.23 \mathrm{kWh} /$ day, which is 2.638 MWh annual electrical energy demand, with $9.5 \%$ ( $\sim .68 \mathrm{kWh} /$ day) of the total daily electrical energy consumption representing energy demand for lighting. The daily energy consumption of the representative household seems adequate in comparison with estimates presented in the open domain [45] [54] [55]

Table 1. Representative sites for solar resource assessment.

\begin{tabular}{cccc}
\hline Geo-political zones & Representative Site & Geographical location & Elevation (m) \\
\hline North-Centre (NC) & Abuja & $9^{\circ} 4.6^{\prime} \mathrm{N}, 7^{\circ} 23.9^{\prime} \mathrm{E}$ & 476 \\
North-East (NW) & Maiduguri & $11^{\circ} 49.9^{\prime} \mathrm{N}, 13^{\circ} 9.1^{\prime} \mathrm{E}$ & 354 \\
North-West (NW) & Gusau & $12^{\circ} 9.8^{\prime} \mathrm{N}, 6^{\circ} 40.5^{\prime} \mathrm{E}$ & 451 \\
South-East (SE) & Enugu & $6^{\circ} 27.5^{\prime} \mathrm{N}, 7^{\circ} 32.8^{\prime} \mathrm{E}$ & 142 \\
South-South (SS) & Port-Harcourt & $4^{\circ} 48.9^{\prime} \mathrm{N}, 7^{\circ} 3.0^{\prime} \mathrm{E}$ & 20 \\
South-West (SW) & Ibadan & $7^{\circ} 22.7^{\prime} \mathrm{N}, 3^{\circ} 56.8^{\prime} \mathrm{E}$ & 181
\end{tabular}




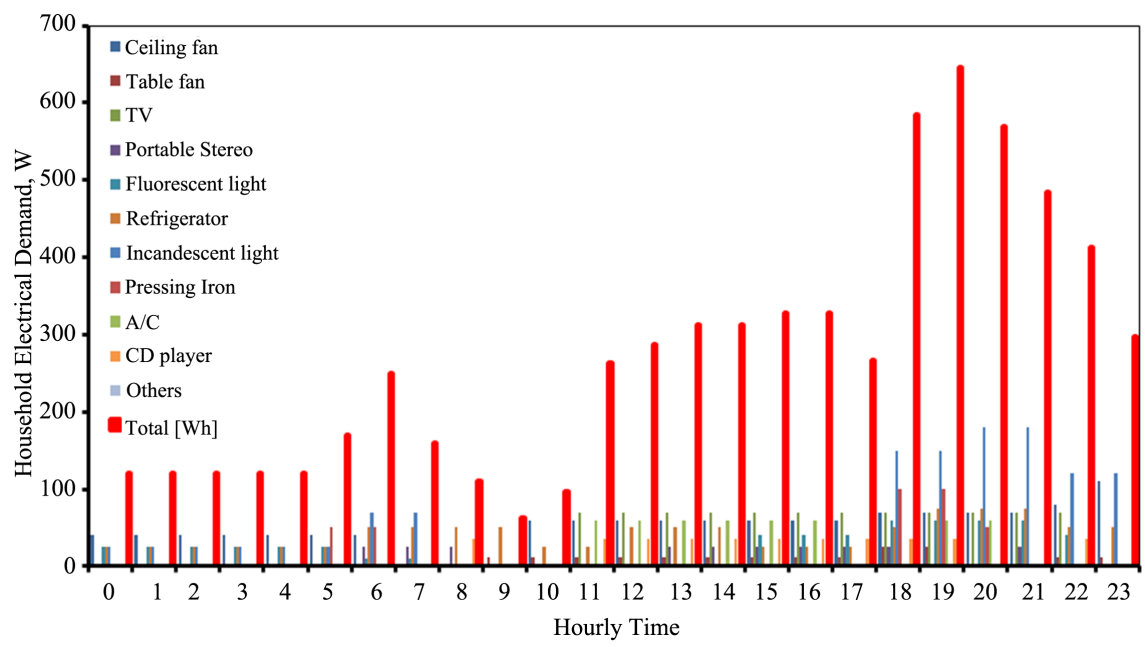

Figure 3. Typical household daily electrical energy demand [56].

[57] and the doubling effect of electricity demand every 12 years. As suggested in [58], the proposed energy system could serve both the medium energy demands $(7.23 \mathrm{kWh} /$ day) and low energy demands (under $0.8 \mathrm{kWh}$ ) consumers in order to adequately drive the SDG 7 access agenda.

\subsection{System Modelling}

A standalone PV system is considered for modelling. The system configuration of the standalone system or remote area power supply system comprises PV arrays, batteries, inverter, charge controller and balance-of-system. To assess the feasibility and the optimal design of a standalone PV electrification system, the HOMER software ${ }^{2}$ was used for the modelling. Optimisation and sensitivity computational algorithms of the HOMER software allow the rapid and robust techno-economic evaluations of various energy technology options by accounting for the cost of energy alternatives and availability of renewable energy resources. The HOMER software has high computation fidelity within the comity of hybrid energy system design platforms. The HOMER uses the load demand, the resources, the details of the components (with costs), the constraints, the systems control and the emission data as an input to simulate various feasible configurations and ranked by the net present cost (NPC). The NPC, which is the present cost of the system minus the sum of revenues, serves as the objective function, with charging and discharging of the energy storage device, power balance and other techno-economic considerations representing the constraints. HOMER obtains the best system configuration after balancing energy demand and supply for each hour of the system simulation [59].

The power output of PV arrays, which generate direct current (DC) voltage when the solar irradiance incident on the PV arrays, can be estimated according to [60] [61]:

${ }^{2}$ The HOMER, which stands for Hybrid Optimisation Model for Electric Renewable, was developed by the US NREL for both grid-tied and stand-alone energy applications. 


$$
P_{\text {out }}=P_{\text {rated }} \times f_{p v}\left(\frac{G}{G_{r e f}}\right) \times\left[1+K_{T, p v}\left(T_{c}-T_{r e f}\right)\right]
$$

where $P_{\text {rated }}(\mathrm{kW})$ is rated power of the PV panel at standard test condition (STC), $f_{p v}(\%)$ is the PV derating factor, $G_{r e f}\left(\mathrm{~kW} / \mathrm{m}^{2}\right)$ is the radiation at STC, $G\left(\mathrm{~kW} / \mathrm{m}^{2}\right)$ is the global solar irradiance incident on the PV surface, $K_{T, p v}$ $(-)$ is the temperature coefficient of the PV module, $T_{r e f}\left({ }^{\circ} \mathrm{C}\right)$ is the cell temperature at STC and $T_{c}\left({ }^{\circ} \mathrm{C}\right)$ is the PV cell temperature. The PV cell temperature can be approximated as $T_{c}=T_{a m b}+0.0256 G$ according to Duffie and Beckman [62], respectively; where $T_{a m b}$ is the ambient temperature. It should be noted that the PV module efficiency is moderately dependent on wind and humidity according to [63] [64], and as such, the effects of wind and humidity were not considered in the current analysis.

The excess DC power generated by the PV is stored in a battery at fixed round trip efficiency. The battery storage capacity can be computed as follows [60]:

$$
C_{W h}=\left(E_{L} \times D_{\text {aut }}\right) /\left(\eta_{\text {inv }} \times \eta_{\text {Batt }} \times \mathrm{DOD}\right)
$$

where $E_{L}, D_{\text {aut }}, \eta_{\text {inv }}, \eta_{\text {Batt }}$ and DOD are the average daily load energy (kWh/ day), the number of days of battery autonomy, the inverter efficiency, the battery efficiency and the battery depth-of-discharge.

The NPC or the Net Present Value (NPV) of a system can be related to the Annualised Life Cycle Cost (ALCC) of the system, which represents the present day worth of money, as [60] [65]

$$
\mathrm{ALCC}=F(i, N) \mathrm{NPC}
$$

where $F(i, N)$ is the system capital recovery factor, which is related as;

$$
F(i, N)=\frac{i(1+i)^{N}}{(1+i)^{N}-1}
$$

The levelised cost of electricity (LCOE), which represents the average cost per $\mathrm{kWh}$ of the electrical energy generated by the system, can be calculated as;

$$
\mathrm{LCOE}=\frac{\mathrm{ALCC}}{E_{s}}
$$

where $E_{s}(\mathrm{kWh} / \mathrm{year})$ is the actual electrical energy served by the system.

All the basic technical and economic calculations, Equations (1) through (5), are appended in the HOMER Software computational algorithm.

The economic merit of an energy system could also be measured using the break-even point (BEP) or the payback time (PBT), in years, which accounts for the number of years it would take to fully recover the initial capital investment. The simple analysis of BEP can be done using Equation (6).

$$
\mathrm{BEP}=\frac{C_{I N V}}{E_{s} * \mathrm{UEC}}
$$

where $C_{I N V}(\$)$ and UEC $(\$ / \mathrm{kWh})$ are, respectively, initial capital investment and cost of a unit of electrical energy consumed, which is taken as $0.434 \mathrm{\$} / \mathrm{kWh}$ 
according to the proposed feed-in-tariff presented in the draft Renewable Energy Master Plan (REMP) of the Energy Commission of Nigeria [66].

\section{Component Assessment}

The cost estimates presented in Diemuodeke et al. [58] for a solar Photovoltaic electrification system are adopted for the current analysis.

$P V$ Arrays. The PV panel estimated cost is US $\$ 2.5 / \mathrm{W}_{\mathrm{p}}$; the replacement and maintenance costs are respectively, US\$ $1.9 / \mathrm{W}_{\mathrm{p}}$ and US\$ $100 /$ year. The cost, which includes a support structure, civil work, the balance of system and land acquisition, is predicated on the extensive research on the Nigerian market. The PV panel is rated $250 \mathrm{~W}_{\mathrm{p}}$ (at $1000 \mathrm{~W} / \mathrm{m}^{2}$ and $25^{\circ} \mathrm{C}$ ) and $31 \mathrm{~V}$, with a derating factor of $90 \%$, and $14 \%$ module efficiency. The expected lifespan of the PV panel is assumed to be 25 years [15].

Batteries: The cost of the battery is US\$ 300 and US\$ 240 for capital and replacement, respectively, in the Nigeria economy, with the following nominal performance specifications: $6 \mathrm{~V}$ maximum power voltage, $230 \mathrm{Ah}(1.38 \mathrm{kWh})$ capacity and $85 \%$ battery efficiency. The suggested battery has a life span of 5 years.

Converter. The converter embodies the inverter and the charge controller, with an estimated cost of US\$ $0.30 / \mathrm{W}$ and $90 \%$ efficiency. The lifespan of the inverter was estimated at 15 years. The converter has the capacity of meeting the power demand of the household.

Economic input: The prevailing discount rate and depreciation under Nigeria's stable economy are adopted as $9 \%$ and $8 \%$, respectively, according to [25] [56]. The project lifespan is considered to be 25 years to match the PV panel life span. However, PV panels are warranted between 25 and 30 years life span [15]; this will form the basis for some of the sensitivity analyses.

\section{Results and Discussion}

\subsection{Results of Solar Resource Assessment}

Figure 6 represents the monthly averaged solar irradiance of the selected sites within the six geo-political zones of Nigeria. The potential of PV is dependent on solar irradiance and the clearness index. The monthly averages of the available daily solar data of the sites were considered. The monthly and annual averaged solar irradiance range between $3.393-6.669 \mathrm{kWh} / \mathrm{m}^{2} /$ day and $4.419-5.813$ $\mathrm{kWh} / \mathrm{m}^{2} /$ day, respectively, and varies along the geo-political zones, as shown in Figure 6, which can be validated by the Nigeria solar map presented in SOLARGIS website [67]. The variation is attributed to the different climatic conditions found in the country-Sahel Savannah, Sudan Savannah, Guinea Savannah, Tropical Rain-forest and Mangrove Swamp-forest. The minimum and maximum solar insolation occur in the Mangrove Swamp-forest (the South-South zone) and the Sahel Savannah (the North-West), respectively. Specifically, the Northern zones feature climatic conditions of a tropical dry climate, with raining season setting from June through September; whereas the Southern zones fea- 
ture tropical dry and wet climatic conditions (double rainfall maxima) which can be attributed to an inter-tropical convergence zone passing through the sites in the Southern zones [45]. The average solar irradiance suggests that between the month of June and September the irradiance is low. The months between June and September are associated with the raining season. However, the months between January and June feature the highest solar irradiance, which are associated with the dry season. The months of November and December feature moderate solar irradiance; these months are associated with the Harmattan season. The comprehensive data of the solar radiation data presented in Figure 4 serve as input data for the techno-economic analysis of the PV energy system as demonstrated in [58].

In all the sites considered, the Northern geo-political zones have better solar irradiance than the Southern geo-political zones. However, it can be inferred from the solar irradiance data that Nigeria has a good potential for solar energy conversion system, PV for example.

\subsection{Results of Techno-Economic Analysis}

The extensive cost estimates of the PV components presented in Section 2.3.1 are used as the input data for the optimal system design and the sensitivity analysis on the HOMER software platform. Table 2 shows the optimal design results

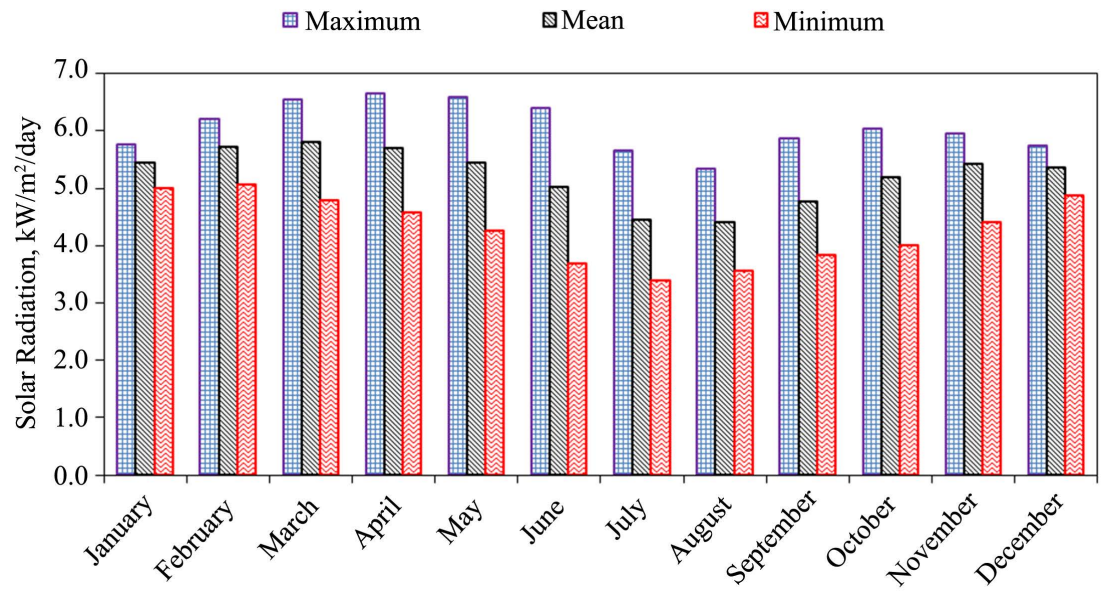

Figure 4. Solar radiation data.

Table 2. Design results for fixed tilted surface.

\begin{tabular}{cccccccc}
\hline $\begin{array}{c}\text { Geo-political } \\
\text { zone }\end{array}$ & $\begin{array}{c}\text { Solar } \\
\text { PV }(\mathrm{kW})\end{array}$ & $\begin{array}{c}\text { Battery } \\
(\mathrm{kWh})\end{array}$ & $\begin{array}{c}\text { Converter } \\
(\mathrm{kW})\end{array}$ & $\begin{array}{c}\text { COE } \\
(\$ / \mathrm{kWh})\end{array}$ & $\begin{array}{c}\text { Initial } \\
\text { Investment }(\$)\end{array}$ & $\begin{array}{c}\text { NPC } \\
(\$)\end{array}$ & $\begin{array}{c}\text { Payback } \\
\text { Time }(\text { Year })\end{array}$ \\
\hline $\mathrm{NC}$ & 2.62 & 11 & 1.10 & 0.412 & 10,187 & 23,132 & 9.30 \\
$\mathrm{NE}$ & 2.10 & 11 & 1.03 & 0.387 & 8,850 & 21,707 & 8.08 \\
$\mathrm{NW}$ & 1.99 & 11 & 1.45 & 0.387 & 8,705 & 21,662 & 7.94 \\
$\mathrm{SE}$ & 2.78 & 15 & 1.21 & 0.447 & 11,806 & 25,048 & 10.77 \\
$\mathrm{SS}$ & 3.30 & 16 & 1.04 & 0.475 & 13,361 & 26,665 & 12.19 \\
$\mathrm{SW}$ & 2.82 & 14 & 1.00 & 0.438 & 11,544 & 24,578 & 10.53 \\
\hline
\end{tabular}


(PV capacity, battery capacity, converter rating, cost of unit electricity generated, amount of initial investment, net present cost, and payback time) for a standalone PV system under fixed tilted surface configuration. The fixed tilted surface orientation takes the latitude of the representative sites as the inclined angle, with the surface facing south. The results for the fixed tilted surface show that the designed capacities of the PV arrays and battery-bank are lowest in the NW $\left(1.99 \mathrm{~kW}_{\mathrm{p}}\right.$ and $\left.11 \mathrm{kWh}\right)$; followed by NE $\left(2.10 \mathrm{~kW}_{\mathrm{p}}\right.$ and $\left.11 \mathrm{kWh}\right), \mathrm{NC}\left(2.62 \mathrm{~kW}_{\mathrm{p}}\right.$ and $11 \mathrm{kWh}), \mathrm{SE}\left(2.78 \mathrm{~kW}_{\mathrm{p}}\right.$ and $\left.15 \mathrm{kWh}\right), \mathrm{SW}\left(2.82 \mathrm{~kW}_{\mathrm{p}}\right.$ and $\left.14 \mathrm{kWh}\right)$ and SS $\left(3.30 \mathrm{~kW}_{\mathrm{p}}\right.$ and $\left.16 \mathrm{kWh}\right)$ geo-political zones in that order. The battery-bank capacity has 31 hours electricity supply autonomy. The PV system is able to power the representative household's electrical energy demand for 8322 hours per year, which is $95 \%$ availability or $5 \%$ loss of load probability. The results are marginally in agreement with the PV arrays and battery-bank capacities obtained for three geo-political zones in Okoye et al. [45]; NW (1.26 $\mathrm{kW}_{\mathrm{p}}$ and $\left.18.82 \mathrm{kWh}\right), \mathrm{SE}$ $\left(2.92 \mathrm{~kW}_{\mathrm{p}}\right.$ and $\left.18.82 \mathrm{kWh}\right)$, and SW $\left(2.84 \mathrm{~kW}_{\mathrm{p}}\right.$ and $\left.18.82 \mathrm{kWh}\right)$, with 48 hours electricity supply autonomy. The difference may be attributed to the $5.4 \mathrm{kWh} /$ day household electrical load, the 48 hours battery bank autonomy, the different representative sites, the intuitive design method and the $2 \%$ loss of load availability probability adopted in Okoye et al.'s [45] methodology. It should be stressed that the intuitive method is vulnerable to over-designing or under-designing of the PV system since intuitive modelling does not consider subsystems components interaction [45].

The levelised cost of electricity (LCOE) and payback time obtained for a fixed tilted surface range between $0.387-0.475 \$ / \mathrm{kWh}$ and $7.9-12.2$ years, respectively, see Table 2 for the details. The LCOE values obtained for the Northern zones are comparable to the LCOE of $0.390 \$ / \mathrm{kWh}$ reported by Adaramola et al. [68] for a PV-hybrid system in the North. On average, the Northern part has LCOE of $0.395 \$ / \mathrm{kWh}$, and the Southern part has LCOE of $0.453 \$ / \mathrm{kWh}$. This is expected as the Northern zones have better solar insolation compare with the Southern zones. Therefore, PV electrification in the Northern zones has more economic competitive advantage over PV electrification in the Southern zones. However, the PV electrification is technically viable (favourable) in all the geo-political zones, since Germany with $2.75 \mathrm{kWh} / \mathrm{m}^{2} /$ day average solar insolation has installed PV capacity that is about 12 times more than the total peak electricity generation in the country.

The $0.423 \$ / \mathrm{kWh}$ average PV LCOE is relatively high when compared to the $0.105 \$ / \mathrm{kWh}$ regulated unit cost of grid electricity generated from the conventional power plants. However, it should be noted that the real unit cost of electricity from the conventional power generation ranges from $0.080-0.109$ US $\$ / \mathrm{kWh}$ without the consideration of about $20 \%$ distribution/transmission losses [69]. The comparison of off-grid PV electricity generation with grid-connected electricity may not be adequate. Moreover, most of the conventional power plants (fossil-fired power plants) do not support green power generation, which are detrimental to the environment with associated climate change impacts. The 
global drive for PV application is to electrify the teeming population living in the rural communities that do not currently have access to the national grid because they are far from the national grid, and are located in remote and rugged terrains with very low energy demand. It is, therefore, necessary to match the levelised cost of electricity from PV with the rural dwellers' monthly income, as demonstrated in the next section.

Figure 5 shows the levelised cost of energy distribution across solar PV, converter and battery. A similar pattern of cost distribution emerges across all zones. On average, it is shown that the battery, constitutes $67 \%$ of the total LCOE, followed by $30 \%$ and $3 \%$ for PV and inverter, respectively. The battery's high percentage contribution is attributed to the frequent replacement (5 times) of the battery over the project's life of 25 years. The implication is that the battery has the strongest effect on the overall system's LCOE, whereas the inverter has a moderate effect on the LCOE of the proposed standalone PV system.

\subsection{Solar PV Affordability}

The estimated initial cost of investment is in the range between $8850-13,361$ US\$ per household with a daily electrical energy demand of $7.23 \mathrm{kWh}$, see details in Table 2. The Northern zones parade the least cost, and the Southern zones have the highest cost of investment. This observation is attributed to the better solar irradiance in the Northern zones over the Southern zones. In the absence of innovative financing mechanisms, the vast majority of the rural dwellers are not in the economic position to afford the huge amount required for an up-front payment of the PV electrification system. This may be attributed to the low income, and pulsating and seasonal income from the agricultural sale that are associated with the rural farmers since a majority of the rural dwellers are into farming. However, PV electrification may not be completely out of the reach of the rural households, but would require designing locally and nationally appropriate financing mechanism. It is expected that the FGN is able to drive the PV utilization, through recognised energy professional and Non-Governmental

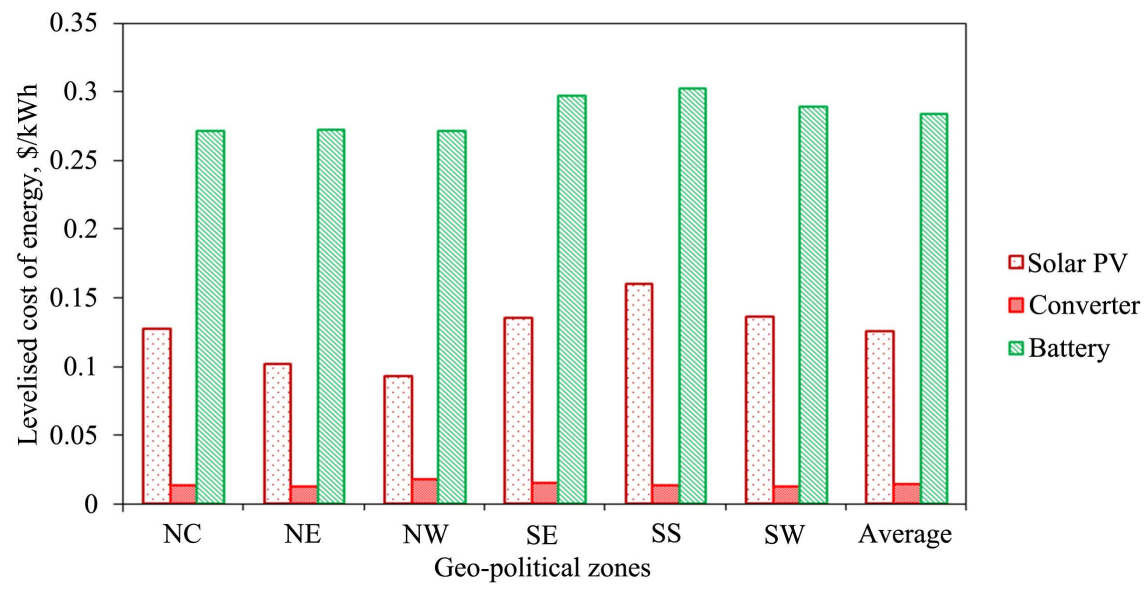

Figure 5. LCOE distribution across components. 
Organisation (NGOs), by establishing PV information dissemination units in all the LGAs and political wards in the six geo-political zones.

There are no available data on the average monthly income of households in the rural areas of Nigeria. However, the Nigerian national minimum wage currently in force [70] is adopted to compute the average monthly income of a rural household to obtain about 195 US $\$ 3$. Assuming a typical rural household that wishes to meet only lighting demands from 6 to 7 am and 7 to $11 \mathrm{pm}$ (i.e. lighting device is used about 5 hours) according to [70], which gives about $9.2 \%$ (about $0.665 \mathrm{kWh} /$ day) of the total daily energy demand for lighting. Using the estimated LCOE for the six geo-political zones, as the maximum acceptable cost of energy, the annual cost of PV for lighting in the zones is shown in Table 3. It should be noted that the economy of scale is not considered in the adoption of the $7.23 \mathrm{kWh}$ /day estimated LCOE as the LCOE for the only lighting scenario. The adoption was made on the premise that the PV power will be provided by energy entrepreneurs, which are driven by profit margin. The table also presents the annual cost of diesel generator and glass-covered kerosene lamp (GKL), which are the most common lighting sources in rural households. The LCOE of diesel generator (DG) is estimated to be $0.947 \$ / \mathrm{kWh}^{4}$, and the LCOE of a glass-covered kerosene lamp is estimated to be $0.559 \$ / \mathrm{kWh}^{5}$.

Table 3. Lighting affordability index.

\begin{tabular}{cccccccc}
\hline \multirow{2}{*}{ System } & \multicolumn{7}{c}{ Geo-political zones } \\
\cline { 2 - 8 } & NC & NE & NW & SE & SS & SW & Average \\
\hline PV annual cost (US\$) & 97.54 & 91.62 & 91.62 & 105.82 & 112.45 & 103.69 & 100.46 \\
DG annual cost (US\$) & 231.24 & 231.24 & 231.24 & 231.24 & 231.24 & 231.24 & 231.24 \\
GKL annual cost (US\$) & 136.50 & 136.50 & 136.50 & 136.50 & 136.50 & 136.50 & 136.50 \\
AI of PV (-) & 4.17 & 3.92 & 3.92 & 4.52 & 4.81 & 4.43 & 4.29 \\
AI of DG (-) & 9.88 & 9.88 & 9.88 & 9.88 & 9.88 & 9.88 & 9.88 \\
AI of GKL (-) & 5.83 & 5.83 & 5.83 & 5.83 & 5.83 & 5.83 & 5.83 \\
\hline
\end{tabular}

${ }^{3}$ The Nigerian national minimum wage is about US $\$ 65 /$ month at an exchange rate of US\$ $1=\mathrm{N} 279$ [70]. The average number of persons in a household in Nigeria is estimated to be five (5) by the National Population Commission, with at least three (3) persons are above 18 years [71]. Therefore, it is assumed that a household has an average of three (3) income-earner members.

${ }^{4}$ The LCOE of the diesel was computed based on market survey data as follows: unit cost of generator is $600 \mathrm{US} \$ / \mathrm{kW}$ (including balance of system), replacement cost is $500 \mathrm{US} \$ / \mathrm{kW}$, fuel cost 1.10 US\$/Litre, maintenance cost is 0.015 US\$/hour and service life is 15,000 hours.

${ }^{5}$ The LCOE of kerosene lamp is computed based on data from survey (market and rural dwellings) and the literature. The average unit cost of glass-covered kerosene lamp $(250 \mathrm{~mL})$ is US\$ 5.2 , the maintenance cost is about $5 \%$ of the capital cost, the lifespan is about 2 years, the fuel cost is 0.9 US\$/Litre, the Lower heating value is $43,200 \mathrm{~kJ} / \mathrm{kg}$ [72] [73], the density of kerosene is $810 \mathrm{~kg} / \mathrm{m}^{3}$, the fuel usage is $8.4 \mathrm{~g} / \mathrm{h}$ and average of 3 lamps per household. There was no available energy conversion efficiency in the open domain, but the value of $12 \%$ was adopted by indirect computation$\eta_{\text {con }}=\frac{\eta_{\text {theL }}}{\eta_{\text {expl }}}$, where $\eta_{\text {theL }}$ and $\eta_{\text {expl }}$ are theoretical luminous efficacy $(0.65 \mathrm{~lm} / \mathrm{W}[73])$ and experimental luminous efficacy $(0.081 \mathrm{~lm} / \mathrm{W}[72])$, respectively—which seems to be adequate. 
Table 3 shows the lighting affordability index $(\mathrm{AI})^{6}$, here defined as the percentage of the annual household income that is used to settle the annual household lighting bill. The household expenditure on PV lighting system is the most affordable, with an affordability index of $4.18 \%$, among the three lighting alternatives considered. It is followed by the glass-covered kerosene lighting device, with an affordability index of $5.83 \%$, and the least is the diesel generator, with 9.88\% affordability index. Besides the poor affordability displayed by the diesel generator and glass-covered kerosene lamp, both have detrimental effects on the environment, which manifest in climate change and health hazards. The glasscovered kerosene lamp impairs on indoor air quality and poses danger to the health of the household occupants. The PV energy system is more affordable in the Northern zones (affordability index ranges from 3.81\% - 4.06\%) compared with the Southern zones (affordability index ranges from $4.32 \%-4.68 \%$ ).

The affordability index analysis undermines the initial cost of investment of the PV system, which is considered to be above the reach of the rural dwellers. However, it is expected that FGN's friendly fiscal and energy policies towards the PV rural electrification, accompany by appropriate funding mechanisms, would absorb or cushion the effect of initial capital cost. These will be demonstrated in the sensitivity analysis, which aims at unveiling the scenarios that would make PV electrification more economically competitive in Nigeria.

\subsection{Results of Sensitivity Analysis}

The discount rate on capital investment, PV panel cost, PV lifespan, battery life, and operating feed-in-tariff have been identified to have a strong effect on the economic competitiveness of PV energy system. Therefore, these factors are varied according to the techno-economic range of the factors as recommended in the literature [3] [5] [16] [44] [45] [74] [75].

\subsubsection{Discount Rate on Capital Investment}

Figure 6 shows the sensitivity analysis of the discount rate on capital investment and its effect on the unit cost of electricity produced. The discount rate values range from $0 \%-12 \%$, with ten years (2007-2016) historic average of $9 \%$ [76]. On average, it is shown that the PV has a superior LCOE over the other two technologies. Increasing the discount rate reduces the gap between the PV LCOE and, GKL and DG LCOEs. It is observed that the GKL LCOE is moderately sensitive to the discount rate. At $0 \%$ discount rate, which is equivalent to the recommendation presented in REMP, the average unit cost of electricity is 0.261 $\$ / \mathrm{kWh}$ for the PV, at $5 \%$ loss of load availability probability, with corresponding percentage decrease of about $38 \%$. The average LCOE value at $0 \%$ gives affordability index of $2.57 \%$ for the $\mathrm{PV}$, which is much more affordable; whereas at $6 \%$ discount rate, the average affordability index is $3.56 \%$, with $15 \%$ corresponding

${ }^{6}$ The $\mathrm{AI}=\frac{365 * \mathrm{LCOE} * \text { Energy Demand } / \text { day }}{\text { Annual Income }} \times 100 \equiv \frac{365 * \text { LCOE } * \text { Energy Demand } / \text { day }}{12 \times \text { Monthly Income }} \times 100$. 


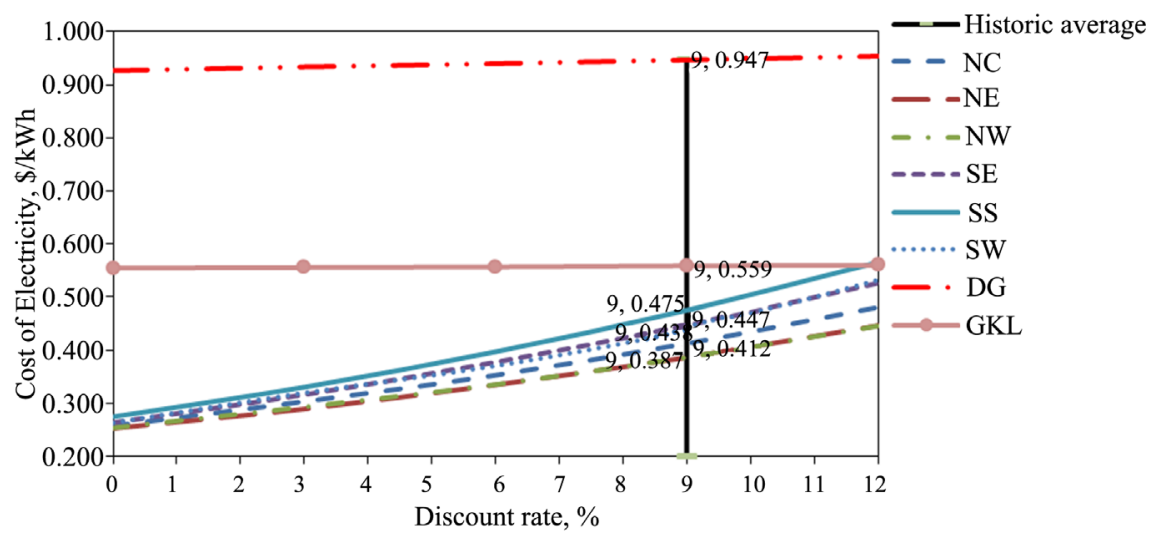

Figure 6. Effect of discount rate on the LCOE.

percentage decrease in LCOE. The implication is that the discount rate has a strong effect on the affordability of the PV system.

\subsubsection{Effect of Solar PV Cost}

The effect of PV panel cost on the levelised cost of electricity is presented in Figure 7. The figure shows that decreasing the cost of PV panel decreases the LCOE, making PV more superior to both DG and GKL. It is shown that decreasing the cost of $\mathrm{PV}$ panel by $50 \%$ results in a corresponding decrease in both the LCOE and the affordability index by about $14 \%$. The implication is that the smaller the solar PV cost the more economically competitive of PV over DG and GKL.

\subsubsection{Effect of Solar PV Life}

The effect of PV panel lifespan on the levelised cost of electricity is presented in Figure 8. The figure shows that increasing the PV panel lifespan decreases the LCOE. It is shown that increasing the PV panel lifespan from 25 to 30 years at $2 \%$ discount rate results in a corresponding decrease in the LCOE by about $39 \%$. The implication is that the higher the longevity of the solar PV panels and the smaller the discount rate the better the economic competitiveness of the proposed PV energy system.

\subsubsection{Effect of Battery Lifespan}

Figure 9 shows that increasing the battery lifespan decreases the unit cost of electricity, and makes PV more competitive over DG and GKL. This is attributed to the less frequent replacement of the battery. It is shown that increasing the battery lifespan from 5 to 10 years results in a corresponding decrease in LCOE by $7 \%$. However, the unit cost of electricity becomes insensitive to the battery lifespan beyond 7 years for the whole zones considered. The implication is that battery lifespan of 7 years and above is appropriate for the proposed PV system.

\subsubsection{Effect of Battery Cost}

Figure 10 shows that the battery cost has a significant effect on the LCOE of the proposed PV system. It is shown that breakthroughs in battery technology that 


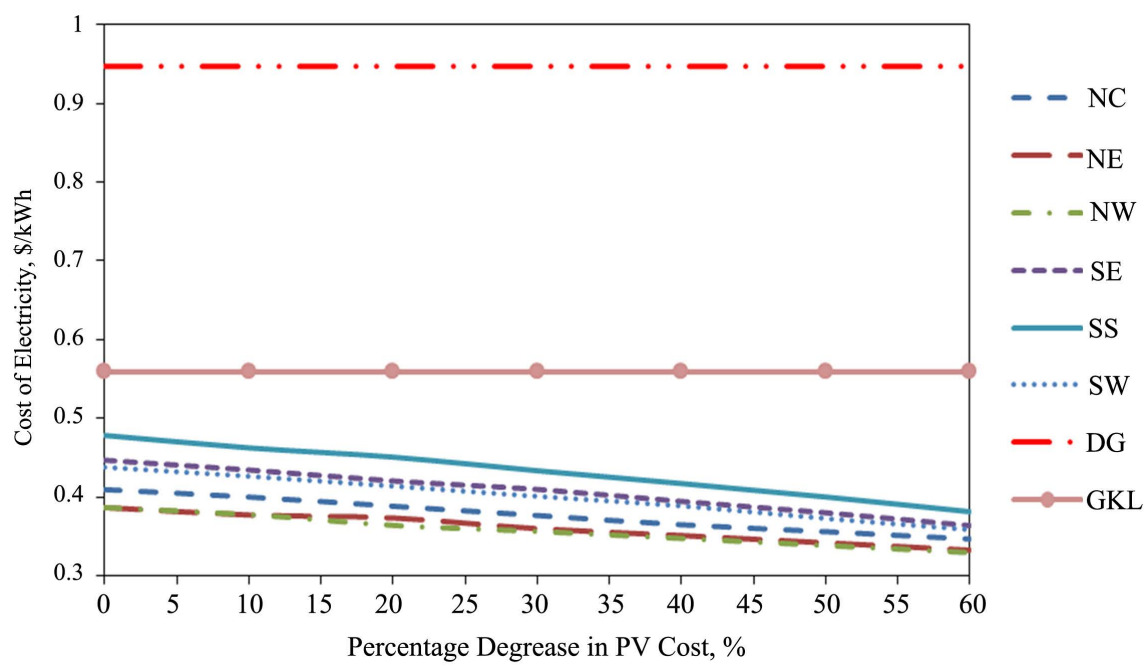

Figure 7. Effect of percentage decrease in PV panel on LCOE.

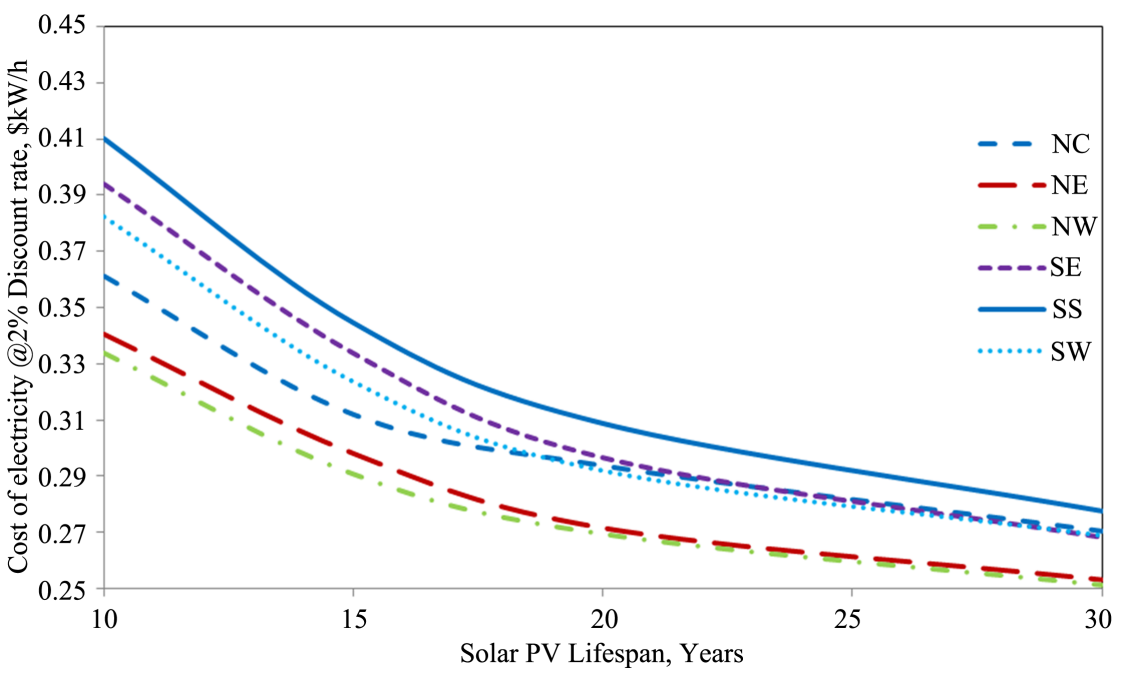

Figure 8. Effect of solar PV lifespan on LCOE.

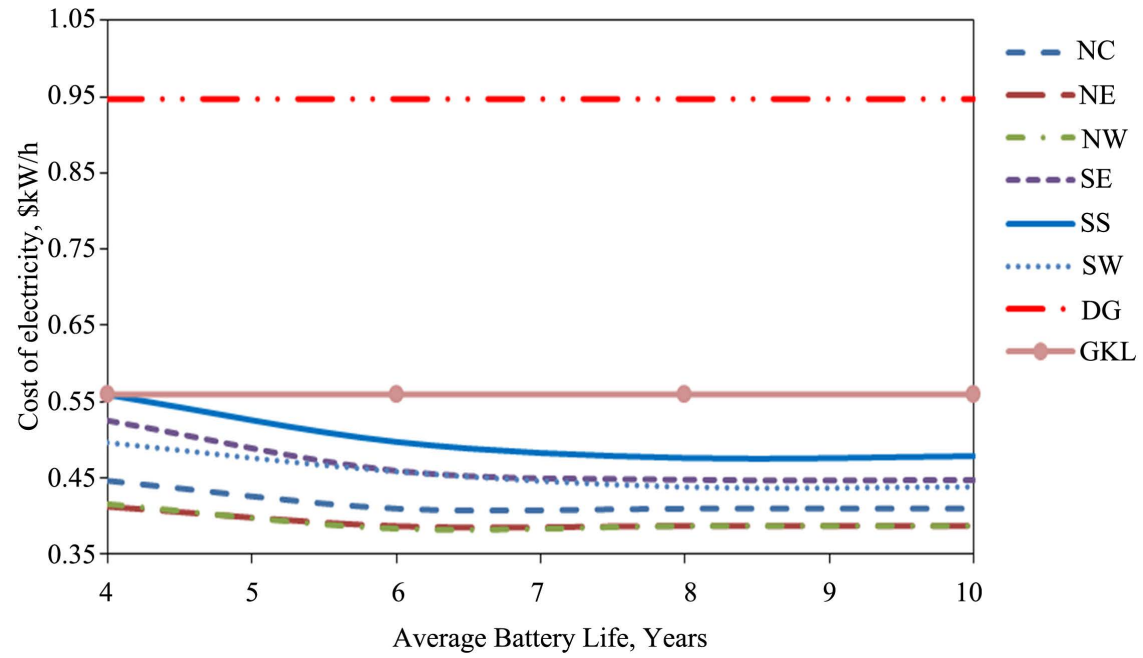

Figure 9. Effect of battery life on cost of electricity. 


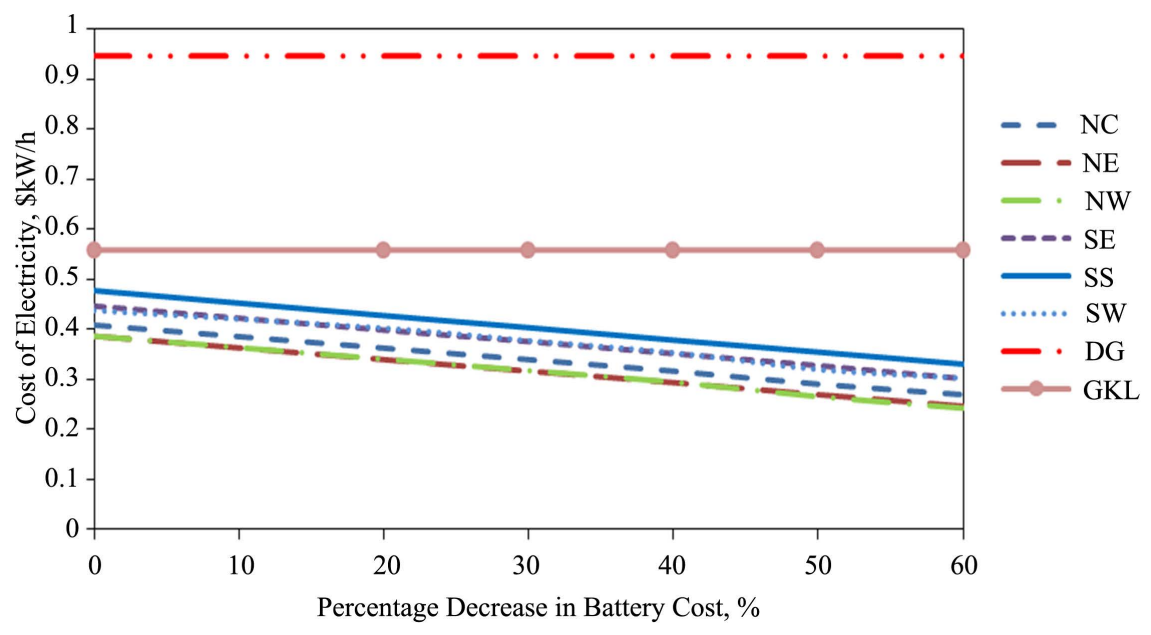

Figure 10. Effect of battery cost on cost of electricity.

would reduce the cost of battery by $60 \%$ would reduce the average overall LCOE by $33.4 \%$. Therefore, research towards drastic cost reduction in battery production technologies should be strongly pursued.

\section{Conclusions}

There is a growing interest in the development and deployment of renewable energy technologies (RETs) as a result of the rapidly declining cost of solar PV $\mathrm{PV})$, the intensified climate change challenges, breakthrough in battery technologies, and energy security. These attributes form the bases for the search for clean, adequate and affordable energy solutions, as stipulated in the No. 7 of the 17 Sustainable Development Goals (SDGs). The rural communities, which are normally in remote and rugged terrain locations, represent the greater percentage of dwelling areas without access to electricity supply, but electricity is required to drive socio-economic developments. Electricity, which is the most demanded energy globally, is required to improve the socio-economic status of rural dwellers. The distributed energy system in which solar PV (PV) is found prominent is favoured as a means of solving the rural electrification problems. Therefore, this paper presents the current PV penetration status in Nigeria and discusses the way forward for aggressive PV penetration in Nigeria energy mix. The current PV penetration in Nigeria is relatively low and shows a significant gap between the FGN's policy targets and reality. The solar resource potential across the six geo-political zones in Nigeria is also presented-ranges from 3.393 - $6.669 \mathrm{kWh} / \mathrm{m}^{2} /$ day, with the Northern zones exhibiting better potentials over the Southern zones. It was established that the unit cost of electricity from PV system ranges from $0.387-0.475$ US $\$ / \mathrm{kWh}$, which are well above the unit cost of grid-connected electricity of $0.105 \mathrm{US} \$ / \mathrm{kWh}$. However, when issues of reliability, speed of connection and hidden subsidies for grid electrification are considered, the off-grid PV energy solution option shows much promise for rural electrification. 
The PV has a competitive economic advantage over diesel generator and glass-covered kerosene lamp for lighting on the basis of their affordability indices. The PV energy system is more affordable in the Northern zones (affordability index ranges from $3.81 \%-4.06 \%$ ) compared with the Southern zones (affordability index ranges from $4.32 \%-4.68 \%$ ). It should be noted that the economy of scale is not considered in the calculation of the affordability index. The household expenditure on PV lighting option, with an affordability index of $4.18 \%$, is the most affordable among the three cases of lighting alternatives considered. It is followed by the glass-covered kerosene lighting device (affordability index of $5.83 \%$ ) and the least is the diesel generator, with a $9.88 \%$ affordability index. The diesel generator and the glass-covered kerosene lamp have a detrimental effect on the environment, which manifest in climate change. The glass-covered kerosene lamp has detrimental effects on indoor air quality that poses danger to the health of the household occupants.

The cost of lighting a rural household under PV electrification is much cost-effective than fossil-fuelled generator and glass-covered kerosene lamp option, even with their detrimental effects on the environment. It can be positioned that the PV is able to serve medium ( $7-8 \mathrm{kWh} /$ day) and low (under $1 \mathrm{kWh}$ ) consumers. The medium consumers would be incentivised to buy into PV because the grid is not reliable, and the low consumers would be driven by the access agenda.

The sensitivity analysis conducted showed that the Federal Government of Nigeria's fiscal and energy policies would accelerate the PV penetration in the country. Specifically, the discount rate on capital investment, PV panel cost and lifespan, and the battery lifespan and cost have been identified to have strong effects on the economic competitiveness of PV energy system. In order to increase the PV penetration in the country, especially in the most energy-deprived areas, the FGN could make the financing of PV systems conducive for low-income households; however, the technical challenges regarding the battery lifespan and cost reside within the global $\mathrm{R} \& \mathrm{D}$ community. The recent breakthroughs in battery technology can become the real game-changers in rural electrification programmes in Nigeria and elsewhere in SSA.

\section{Conflicts of Interest}

The authors declare no conflicts of interest regarding the publication of this paper.

\section{References}

[1] United Nations Development Programme (2015) Sustainable Development Goals (Clean and Affordable Energy). UNDP.

[2] Ko, C.O. (2016) Adequate, Reliable and Sustainable Energy Supply in Nigeria. Nigerian Society of Engineers, Port Harcourt Branch, Engineering Week, 14-20 November 2016.

[3] Karakaya, E. and Sriwannawit, P. (2015) Barriers to the Adoption of Photovoltaic 
Systems: The State of the Art. Renewable \& Sustainable Energy Reviews, 49, 60-66. https://doi.org/10.1016/j.rser.2015.04.058

[4] Stern, D.I. and Cleveland, C.J. (2004) Energy and Economic Growth.

[5] Rydh, C.J. and Sandén, B.A. (2005) Energy Analysis of Batteries in Photovoltaic Systems. Part II: Energy Return Factors and Overall Battery Efficiencies. Energy Conversion and Management, 46, 1980-2000. https://doi.org/10.1016/j.enconman.2004.10.004

[6] Aslani, A., Helo, P. and Naaranoja, M. (2013) Evaluation of Renewable Energy Development in Power Generation in Finland. The Journal of Renewable and Sustainable Energy, 5, Article ID: 063132. https://doi.org/10.1063/1.4855095

[7] Diemuodeke, E.O. and Oko, C.O.C. (2013) Optimum Configuration and Design of a Photovoltaic-Diesel-Battery Hybrid Energy System for a Facility in University of Port Harcourt, Nigeria. International Journal of Ambient Energy, 37, 2-9. https://doi.org/10.1080/01430750.2013.866906

[8] Ohunakin, O.S., Adaramola, M.S., Oyewola, O.M. and Fagbenle, R.O. (2014) Solar Energy Applications and Development in Nigeria: Drivers and Barriers. Renewable \& Sustainable Energy Reviews, 32, 294-301. https://doi.org/10.1016/j.rser.2014.01.014

[9] Dawn, S., Tiwari, P.K., Goswami, A.K. and Mishra, M.K. (2016) Recent Developments of Solar Energy in India: Perspectives, Strategies and Future Goals. Renewable \& Sustainable Energy Reviews, 62, 215-235.

https://doi.org/10.1016/j.rser.2016.04.040

[10] Fakehi Khorasani, A.H., Ahmadi, S. and Moradi, M.A. (2015) The Impact of Energy Conservation Policies on the Projection of Future Energy Demand. Energy Technology \& Policy, 2, 104-121. https://doi.org/10.1080/23317000.2015.1068140

[11] Diemuodeke, E.O., Hamilton, S. and Addo, A. (2016) Multi-Criteria Assessment of Hybrid Renewable Energy Systems for Nigeria's Coastline Communities. Energy, Sustainability and Society, 6, 26. https://doi.org/10.1186/s13705-016-0092-x

[12] Oseni, M.O. (2012) Improving Households' Access to Electricity and Energy Consumption Pattern in Nigeria: Renewable Energy Alternative. Renewable \& Sustainable Energy Reviews, 16, 3967-3974. https://doi.org/10.1016/j.rser.2012.03.010

[13] Thiam, D.R. (2011) Renewable Energy, Poverty Alleviation and Developing Nations: Evidence from Senegal. Journal of Energy in Southern Africa, 22, 23-34. https://doi.org/10.17159/2413-3051/2011/v22i3a3219

[14] Mondal, M.A.H., Bryan, E., Ringler, C. and Rosegrant, M. (2016) 100\% Electrification and Renewable Based Ethiopian Power Sector Development Strategies. 2016 4th International Conference on the Development in the in Renewable Energy Technology (ICDRET), Dhaka, 7-9 January 2016, 1-4.

https://doi.org/10.1109/ICDRET.2016.7421508

[15] Ouedraogo, B.I., Kouame, S., Azoumah, Y. and Yamegueu, D. (2015) Incentives for Rural Off Grid Electrification in Burkina Faso Using LCOE. Renewable Energy, 78, 573-582. https://doi.org/10.1016/j.renene.2015.01.044

[16] Opiyo, N. (2016) A Survey Informed PV-Based Cost-Effective Electrification Options for Rural Sub-Saharan Africa. Energy Policy, 91, 1-11.

https://doi.org/10.1016/j.enpol.2015.12.044

[17] Sandwell, P., et al. (2016) Off-Grid Solar Photovoltaic Systems for Rural Electrification and Emissions Mitigation in India. Solar Energy Materials and Solar Cells, 156, 147-156. https://doi.org/10.1016/j.solmat.2016.04.030 
[18] Wirth, H. (2016) Recent Facts about Photovoltaics in Germany.

[19] Federal Ministry of Power (2015) National Renewable Energy and Energy Efficiency Policy.

[20] World Bank (2015) Power Outages in Firms in a Typical Month (Number), World Bank Enterprise Survey. World Bank, Washington DC.

[21] US Energy Information Association (2016) Energy Review. EIA.

[22] Nygaard, I. and Dafrallah, T. (2016) Utility Led Rural Electrification in Morocco: Combining Grid Extension, Mini-Grids, and Solar Home Systems. Wiley Interdisciplinary Reviews: Energy and Environment, 5, 155-168. https://doi.org/10.1002/wene.165

[23] Kemausuor, F. and Ackom, E. (2017) Toward Universal Electrification in Ghana. Wiley Interdisciplinary Reviews. Energy and Environment, 6, e225. https://doi.org/10.1002/wene.225

[24] GIZ (2015) The Nigerian Energy Sector: An Overview with a Special Emphasis on Renewable Energy, Energy Efficiency and Rural Electrification.

[25] Gujba, H., Mulugetta, Y. and Azapagic, A. (2010) Environmental and Economic Appraisal of Power Generation Capacity Expansion Plan in Nigeria. Energy Policy, 38, 5636-5652. https://doi.org/10.1016/j.enpol.2010.05.011

[26] Adewale, G., Adetunji, A., Ahmed, Y. and Olukan, T. (2017) A Comprehensive Review on Biomass and Solar Energy for Sustainable Energy Generation in Nigeria. Renewable \& Sustainable Energy Reviews, 69, 620-641. https://doi.org/10.1016/j.rser.2016.11.160

[27] Ayodele, E.O. and Alabi, O.M. (2011) Abandonment of Construction Projects in Nigeria: Causes and Effects. Journal of Emerging Trends in Economics and Management Sciences, 2, 142-145.

[28] Shaaban, M. and Petinrin, J.O. (2014) Renewable Energy Potentials in Nigeria: Meeting Rural Energy Needs. Renewable \& Sustainable Energy Reviews, 29, 72-84. https://doi.org/10.1016/j.rser.2013.08.078

[29] Gabriel, C. (2016) What Is Challenging Renewable Energy Entrepreneurs in Developing Countries? Renewable \& Sustainable Energy Reviews, 64, 362-371. https://doi.org/10.1016/j.rser.2016.06.025

[30] Verbrugen, A. and Lauber, V. (2009) Basic Concepts for Designing Renewable Electricity Support Aiming at a Full-Scale Transition by 2050. Energy Policy, 37, 5732-5743. https://doi.org/10.1016/j.enpol.2009.08.044

[31] Akuru, U.B., Onukwube, I.E., Okoro, O.I. and Obe, E.S. (2017) Towards 100\% Renewable Energy in Nigeria. Renewable \& Sustainable Energy Reviews, 71, 943-953. https://doi.org/10.1016/j.rser.2016.12.123

[32] Nwokocha, C.O., Okoro, U.K. and Usoh, C.I. (2018) Photovoltaics in Nigeria-Awareness, Attitude and Expected Benefit Based on a Qualitative Survey across Regions Renewables (Mostly from Hydroelectricity) Dry Natural Gas. Renewable Energy, 116, 176-182. https://doi.org/10.1016/j.renene.2017.09.070

[33] Schwerhoff, G. and Sy, M. (2017) Financing Renewable Energy in Africa-Key Challenges of the Sustainable Development Gooals. Renewable \& Sustainable Energy Reviews, 75, 393-401. https://doi.org/10.1016/j.rser.2016.11.004

[34] Deichmann, U., Meisner, C., Murray, S. and Wheeler, D. (2011) The Economics of Renewable Energy Expansion in Rural Sub-Saharan Africa. Energy Policy, 39, 215-227. https://doi.org/10.1016/j.enpol.2010.09.034

[35] Bensch, G., Peters, J. and Sievert, M. (2017) The Lighting Transition in Rural Afri- 
ca-From Kerosene to Battery-Powered LED and the Emerging Disposal Problem. Energy for Sustainable Development, 39, 13-20. https://doi.org/10.1016/j.esd.2017.03.004

[36] Shahzad, K., et al. (2018) An Ecological Feasibility Study for Developing Sustainable Street Lighting System Kingdom of Saudi Arabia. Journal of Cleaner Production, 175, 683-695. https://doi.org/10.1016/j.jclepro.2017.12.057

[37] Mills, E. (2016) Identifying and Reducing the Health and Safety Impacts of Fuel-Based Lighting. Energy for Sustainable Development, 30, 39-50. https://doi.org/10.1016/j.esd.2015.11.002

[38] Alstone, P. and Jacobson, A. (2018) LED Advances Accelerate Universal Access to Electric Lighting. Comptes Rendus Physique, 19, 146-158.

https://doi.org/10.1016/j.crhy.2017.10.015

[39] Baurzhan, S. and Jenkins, G.P. (2016) Off-Grid Solar PV: Is It an Affordable or Appropriate Solution for Rural Electrification in Sub-Saharan African Countries? Renewable \& Sustainable Energy Reviews, 60, 1405-1418.

https://doi.org/10.1016/j.rser.2016.03.016

[40] Sambo, A. and Bala, E. (2012) Penetration of Solar Photovoltaic into Nigeria's Energy Supply Mix. World Renewable Energy Forum (WREF), Denver, 13-17 May 2012, 1-9.

[41] Daily Trust (2017) Discordant Tunes over 6 Geo-Political Zones.

[42] Aliyu, S.A., Dada, J.O. and Khalil, I. (2015) Current Status and Future Prospects of Renewable Energy in Nigeria. Renewable \& Sustainable Energy Reviews, 48, 336-346. https://doi.org/10.1016/j.rser.2015.03.098

[43] Ozoegwu, C.G., Mgbemene, C.A. and Ozor, P.A. (2017) The Status of Solar Energy Integration and Policy in Nigeria. Renewable \& Sustainable Energy Reviews, 70, 457-471. https://doi.org/10.1016/j.rser.2016.11.224

[44] IRENA (2016) Solar PV in Africa: Cost and Market.

[45] Okoye, C.O., Taylan, O. and Baker, D.K. (2016) Solar Energy Potentials in Strategically Located Cities in Nigeria: Review, Resource Assessment and PV System Design. Renewable \& Sustainable Energy Reviews, 55, 550-566.

https://doi.org/10.1016/j.rser.2015.10.154

[46] Nwofe, P.A. (2014) Utilization of Solar and Biomass Energy-A Panacea to Energy Sustainability in a Developing Economy. International Journal of Energy and Environmental Research, 2, 10-19.

[47] EBR (2016) Nigeria's NBET Signs \$1.76bn Deals to Purchase 1,125MW of Solar Power. EBR.

[48] Detail Commercial Solicitors (2016) Prospects of Solar Power Generation in Diversifying Nigeria's Energy. No. August, 1-5.

[49] REN21 (2016) Renewables 2016: Global Status Report.

[50] AfDB (2018) Nigerian Electrification Project-Appraisal Report.

[51] Yetano Roche, M., Verolme, H., Agbaegbu, C., Binnington, T., Fischedick, M. and Oladipo, E.O. (2019) Achieving Sustainable Development Goals in Nigeria's Power Sector: Assessment of Transition Pathways. Climate Policy, 20, 846-865. https://doi.org/10.1080/14693062.2019.1661818

[52] Scott, A. and Miller, C. (2016) Accelerating Access to Electricity in Africa with Off-Grid Solar the Impact of Solar Household Solutions. Overseas Development Institute.

[53] Tesema, S. (2014) Resource Assessment and Optimization Study of Efficient Type 
Hybrid Power System for Electrification of Rural District in Ethiopia. International Journal of Energy and Environmental Engineering, 3, 331. https://doi.org/10.11648/j.ijepe.20140306.16

[54] Adeoti, O., Oyewole, B.A. and Adegboyega, T.D. (2001) Solar Photovoltaic-Based Home Electrification System for Rural Development in Nigeria: Domestic Load Assessment. Renewable Energy, 24, 155-161. https://doi.org/10.1016/S0960-1481(00)00188-9

[55] Ogbonna, A.C., Onazi, O. and Dantong, J.S. (2011) Domestic Energy Consumption Patterns in a Sub Sahara Africa City: The Study of Jos-Nigeria. Journal of Environmental Science and Management, 3, 48-62.

[56] Diemuodeke, E.O., Addo, A., Dabipi-Kalio, I., Oko, C.O.C. and Mulugetta, Y. (2017) Domestic Energy Demand Assessment of Coastline Rural Communities with Solar Electrification. Energy and Policy Research, 4, 1-9.

https://doi.org/10.1080/23815639.2017.1280431

[57] Ajao, K.R., Oladosu, O. and Popoola, O. (2011) Using HOMER Power Optimization Software for Cost Benefit Analysis of Hybrid-Solar Power Generation Relative to Utility Cost in Nigeria. International Journal of Research and Reviews in Applied Sciences, 7, 96-102.

[58] Diemuodeke, E.O., Addo, A., Oko, C.O.C., Mulugetta, Y. and Ojapah, M.M. (2019) Optimal Mapping of Hybrid Renewable Energy Systems for Locations Using Multi-Criteria Decision-Making Algorithm. Renewable Energy, 134, 461-477. https://doi.org/10.1016/j.renene.2018.11.055

[59] Shahzad, M.K., Zahid, A., Rashid, T., Rehan, M.A., Ali, M. and Ahmad, M. (2017) Techno-Economic Feasibility Analysis of a Solar-Biomass Off Grid System for the Electrification of Remote Rural Areas in Pakistan Using HOMER Software. Renewable Energy, 106, 264-273. https://doi.org/10.1016/j.renene.2017.01.033

[60] Olatomiwa, L. (2016) Optimal Configuration Assessments of Hybrid Renewable Power Supply for Rural Healthcare Facilities. Energy Reports, 2, 141-146. https://doi.org/10.1016/j.egyr.2016.06.001

[61] Lambert, T., Gilman, P. and Lilienthal, P. (2006) Micropower System Modeling with Homer. In: Farret, F.A. and Simões, M.G., Eds., Integration of Alternative Sources of Energy, John Wiley and Sons, Hoboken, 379-418. https://doi.org/10.1002/0471755621.ch15

[62] Duffie, J.A. and Beckman, W.A. (1991) Solar Engineering of Thermal Processes. 2nd Edition, Wiley, New York.

[63] Kaldellis, J.K., Kapsali, M. and Kavadias, K.A. (2014) Temperature and Wind Speed Impact on the Efficiency of PV Installations. Experience Obtained from Outdoor Measurements in Greece. Renewable Energy, 66, 612-624. https://doi.org/10.1016/j.renene.2013.12.041

[64] Bhattacharya, T., Chakraborty, A.K. and Pal, K. (2014) Effects of Ambient Temperature and Wind Speed on Performance of Monocrystalline Solar Photovoltaic Module in Tripura, India. Journal of Solar Energy, 2014, Article ID: 817078. https://doi.org/10.1155/2014/817078

[65] Oko, C.O.C., Diemuodeke, E.O., Omunakwe, N.F. and Nnamdi, E. (2012) Design and Economic Analysis of a Photovoltaic System: A Case Study. International Journal of Renewable Energy Development, 1, 65-73.

https://doi.org/10.14710/ijred.1.3.65-73

[66] FGN, ECN, and UNDP (2012) Draft Renewable Energy Master Plan.

[67] SOLARGIS (2017) Solar Resource Map. SOLARGIS. 
[68] Adaramola, M.S., Paul, S.S. and Oyewola, O.M. (2014) Assessment of Decentralized Hybrid PV Solar-Diesel Power System for Applications in Northern Part of Nigeria. Energy for Sustainable Development, 19, 72-82. https://doi.org/10.1016/j.esd.2013.12.007

[69] Bloomberg New Energy Finance (2015) Levelised Cost of Electricity: DFID Priority Countries.

[70] FGN (2015) The National Minimum Wage Regulations 2015.

[71] National Population Commission (2010) Population by Size-Class of Household. National Population Commission.

[72] Mills, E. (2005) The Specter of Fuel-Based Lighting. Science, 301, 1263. https://doi.org/10.1126/science.1113090

[73] Machala, M. (2011) Kerosene Lamps vs. Solar Lanterns. Stanford University, Stanford.

[74] Kolhe, M., Kolhe, S. and Joshi, J.C. (2002) Economic Viability of Stand-Alone Solar Photovoltaic System in Comparison with Diesel-Powered System for India. Energy Economics, 24, 155-165. https://doi.org/10.1016/S0140-9883(01)00095-0

[75] Azoumah, Y., Yamegueu, D., Ginies, P., Coulibaly, Y. and Girard, P. (2011) Sustainable Electricity Generation for Rural and Peri-Urban Populations of Sub-Saharan Africa: The "Flexy-Energy" Concept. Energy Policy, 39, 131-141.

https://doi.org/10.1016/j.enpol.2010.09.021

[76] Trading Economics (2017) Interest Rate in Nigeria. 